\section{Pre- and Postharvest Practices for Improved Vegetable Transplant Quality}

\author{
Daniel J. Cantliffe
}

Additional index words. seedling, transplant height, nutrition, transplant age, transplant storage, transplant handling

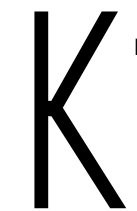

nowledge of proper conditions for transplant pre- and postharvest handling and shipping are not understood clearly by many shippers and growers. In fact, few studies have dealt with improving transplant performance and early seedling growth via new shipping and handling technology. My purpose is to bring into focus some factors that directly or indirectly affect pre- and postharvest transplant quality, betterearly plant growth, and higher yield.

Price and Zandstra (1988) reported that any cessation in plant growth caused adverse cropping response (i.e., seedstalk development), greater disease susceptibility, and, potentially, reduced yield. Thus, plant growth should never be interrupted, whether the crop is grown directly from seed or from a transplant. This is difficult in practice, especially when one considers that transplants might be shipped long distances in the United States $(1800 \mathrm{~km})$, and that growers may be forced to hold the plants for 7 or more days due to adverse environmental conditions (Orzolek, 1989; Wood, 1988). When this happens, transplants may survive well in the tray or even in the field, but subsequent growth may become slow and uneven, and may negate any beneficial reasons for transplant use (Wood, 1988).

Several pre- and postharvest handling factors have been studied to a limited extent, and have been relatedto improved transplant quality. They include: 1) controlling plant growth (by varying seedling tray-cell size, fertilization, irrigation, and temperature), by mechanical root or shoot pruning, or using chemical growth retardants; 2) age of the transplant: and 3) conditions of the storage/handling procedures

Horticultural Sciences Department, IFAS, University of Florida, Gainesville, FL 32611-0690.

Florida Agricultural Experiment Station Journal Series No. R-02581.

\section{Preharvest factors that affect postharvest transplant quality}

Transplants grown in large tray-cell sizes generally are taller and have greater leaf area and shoot-root dry weights than those grown in small tray-cell sizes. Weston and Zandstra $(1983,1986)$ found that plants from large cells suffered almost no transplant shock when compared with transslants grown in small cell sizes. For both peppers and tomatoes, they found that plants from larger cells produced larger plants and greater early yields. Harmon et al. (1991) observed similar results with eggplant. Hall (1989) found a similar effect for watermelon, but the effect was cultivardependent, Jones et al. (1991) increased broccoli and cauliflower earliness, but not total yields, by using larger Speedling cell sizes compared to smaller cell sizes. Transplant size obviously will have a profound effect on shipping cost and potentially on plant quality after shipping. Larger plants are simply more difficult to handle and are more expensive.

Dufault (1986) examined pretransplant nutritional conditioning (PNC) as a means to improve tolerance to transplant shock in muskmelon. After examining nine PNC regimes, total harvest did not differ, but earliness and uniform maturity were enhanced as PNC regimes increased (Le., increased fertilization). Dufault proposed that high PNC level predisposed the transplant to recover from shock, and thus resume growth more rapidly than low PNC regimes.

Commercial transplant growers must look continually for methods to control transplantheight. Optimum light, temperature, fertilization, and moisture increase growth rate, succulence, and susceptibility to damage. In the past, growth retardants have been used to control transplant height (Hickman et al., 1989). Orzolek (1989) suggested that growth retardantscan be beneficial both to the transplant producer and farmer, especially if delays occur due to transportation or inclement weather. Unfortunately, daminozide (Alar, B-Nine), the most widely used growth retardant on vegetable transplants (Jaworski et al., 1970; Pisaraczyk and Splittstoesser, 1979; Taha et al., 1980) was removed from the market in 1990. Transplant growers still seek control of transplant height.

Jaworski (1966) first reported the use of clipping transplants to control plant height. Clipped transplants had thicker stems, and it was proposed that such transplants would survive transplanting shock better. If clipping was done 2 days before transplant harvest, fruit yields of tomato were reduced compared to clipping 14 or 17 days prior to transplant harvest (Jaworski and Webb, 1966). More-severe clipping of tomato seedlings $(2.5 \mathrm{~cm}$ or more) reduced usable fruit yields compared to nonclipped or moderately clipped transplants (Jaworski et al., 1969). McCarter and Jaworski (1968: reported that clipping could disseminate certain major tomato disease pathogens. They showed that Pseudomonas solanacearum was spread readily from diseased to healthy tomato plants by various types of clipping. They postulated that other diseases, such as bacterial wilt, could be disseminated readily by clipping.

Brushing is another alternative method to control transplant growth (Latimer, 1991; Latimer and Thomas, 1991). Although brushing is not effective on all species, several, such as tomato (Latimer and Thomas, 1991), responded to brushing by decreasing plant height and leaf area without a decrease in specific leaf dry weight. The potential danger also exists for pathogen dissemination.

Recently, Carlson (1990) outlined strategies o control transplant height using: 1) moisture stress (especially where watering is done only at light); 2) nutrient stress, especially withholding phosphorus; and 3) growing plants under high light intensity or cooler temperatures. The first two methods may retard subsequent plant growth in the field, while the last method may be too expensive for transplant producers. Carlson has published widely on the use of DIF (difference between day and night temperatures) to control plant height. If cost-effective, this may have the least-adverse effect on plant growth after field-planting.

Lower transplant growing temperatures have been identified as a method to control plant height. Wien (1990) reported that maintaining day/night temperatures of 16 to $18 \mathrm{C}$ and night temperatures of 10 to $16 \mathrm{C}$, respectively, for 1 week before transplanting, induced catfacing in tomato. The plants were susceptible to low temperature when embryonic flower initials were first forming. Lower night temperatures (5 to $8 \mathrm{C}$ ) may reduce the potential for catfacing. Temperatures much lower than this can lead to chilling injury in the tomato plant. Wien concluded by suggesting that temperature should not be used to control tomato transplant growth. Dufault and Melton (1990) exposed tomato transplants to $2 \mathrm{C}$ for 3 to $18 \mathrm{~h}$ for 1 to 10 days before transplanting and found no effect on earliness, yield, or quality of tomato fruits. Apparently, different cultivars may react diversely to cold stress.

From the worksummarized above, any technique that retards or interrupts plant growth may be used to control transplant height and growth in the greenhouse. Regardless of method used, all methods may impact postharvest quality and subsequent field growth and yield negatively.

Carlson (1990) stated that "younger plants are shorter plants. Schedule to sell plants sooner and they will be short enough for shipping." This may be the best advice to reduce greenhouse production costs, limit exposure to disease (especially viruses),and maintain actively growing transplants in a form that will ship well and initiate regrowth rapidly after planting.

\section{Age of the transplant and its effect on postharvest quality}

Various studies have reported the effects of transplant age on seedling and field performance 
(Marr and Jirak, 1990). Transplant age affects different species in different ways. Earlier yields were obtained from 7-week-old lettuce transplants produced in open peat-pot containers compared to 3 to 6-week-old plants (Wang and Kratky, 1976). Wurr and Fellows (1986) produced lettuce transplants in tightly packed Techniculture plugs, and found less head weight variability among 13-and 19-day-old than among 25-day-old transplants.

Transplant age from 3- to 6-week-old plants did not affect yield of Chinese cabbage yield grown in cylindrical polyethylene sleeves $(2.5,3.75,5$, and $7.5 \mathrm{~cm}$ in diameter and $6.4 \mathrm{~cm}$ deep) (Kratky et al., 1982). Container size had a profound influence on plant growth. Plants from the largest container size matured earlier, produced heavier heads, and yielded $25 \%$ to $31 \%$ more than plants from the smallest containers.

Weston (1988) reported that 60-day-old pepper transplants had greater earlier yield of large fruit than those grown for 30,40 , or 50 days. Total yields of all fruit sizes were unaffected by transplant age. Marketable cauliflower curd yields were unaffected by using 5 - to 8-week-old transplants grown in small cells (Wurr et al., 1986). Transplant age did not affect cabbage yields; however, older broccoli and cauliflower transplants produced greater early yields in fall plantings, but not necessarily in the spring plantings (Jones et al., 1991).

In one of the first reports discussing the benefits of younger transplants for tomato production, Nicklow and Minges (1962) observed greater early fruit yields from 3- to 5-week-old bare-root tomato transplants than 7- or 9-week-old transplants. They recorded fruit yields of $38 \mathrm{t} \mathrm{ha}{ }^{-1}$ from 43-day-old transplants, compared to $17 \mathrm{t} \mathrm{ha}^{-1}$ from 60-day-old transplants. Plant height, leaf area, and shoot weight increased uniformly as transplant age of containerized transplants increased from 3 to 6 weeks (when one growth measurement was taken at the time of transplanting) (Weston and Zandstra, 1989). The 4- and 5week-old transplants had the greatest early yield, but total yields were similar from 3-, 4-, and 5week-old transplants.

Leskovar et al. (1991) studied the response of different-aged transplants of Sunny tomato seedling growth and yield grown under fall and spring conditions in Florida. The plants, grown in commercial transplant houses, were planted and harvested in commercial producer fields. Stem length and leaf area increased linearly with increasing transplant age 1 and 2 weeks after transplanting in the spring. However, during the first week of growth, 3- and 4-week-old transplants grew significantly faster $\left[0.107 \mathrm{~g} \mathrm{~g}^{-1}\right.$ day ${ }^{-1}$ relative growth rate (RGR)] than older $\left(0.064 \mathrm{~g} \mathrm{~g}^{-1}\right.$ day $^{-1}$ ) transplants. From 2 to 3 weeks after transplanting, 4-week-old plants had significantly greater plant and root RGR $\left(0.124 \mathrm{~g} \mathrm{~g}^{-1}\right.$ day $\left.{ }^{-1}\right)$ than g-week-old (0.078) plants. Thus, younger transplants had a greater capacity to resume growth after transplanting than older transplants.
During seedling culture, older (5- and 6week) transplants can be exposed to more water and nutrient stresses than younger (3- and 4week) transplants (Leskovar et al., 1990). Early and total fruit yields were similar from all transplant ages. However, 4- and 5-week transplants yielded more large fruit early, and 4-week transplants had more total yield of large fruit than 6week transplants. Therefore, younger (3- and 4week) transplants, producing similar or higher yields, may be more advantageous to use than older transplants.

In the fall, 4- or 5-week-old tomato transplants were taller than 2-and 3-week plants. Leaf area at transplanting increased linearly as transplant age increased from 2 to 5 weeks, but these differencesdiminished 1 week after transplanting. Early and total marketable fruit yields were similar among transplant age treatments. However, 4week transplants produced more early and total extra large fruit than 5-week transplants.

These studies suggested that under Florida conditions, no improvement in fruit yields could be expected when using the traditional 5 - and 6week-old transplants compared to younger 4- and 5-week transplants during spring and fall, respectively. This work also reiterated that young transplants resume growth faster in the field, and that they can be produced at lower costs because of a shorter greenhouse growth cycle.

\section{Transplant storage and handling}

Initially, the southern transplant industry was based on field-grown bare-root plants that were pulled, tied in bundles of 50, and packed with peat and Kraft paper around the roots. These bundles then were packed in hampers (300 to 450 plants) or wirebound crates (600 to 800 plants). The crates were refrigerated in truck trailers via ice bunkers and circulating fans and then shipped to northern areas. During transport, the peat tended to dry out, which can lead to desiccation of the plants.

Jaworski and Webb (1966) stored bare-root tomato transplants rolled and bundled in peatmoss and Kraft paper and packed in keystoneshaped crates for 5 and 10 days at $10 \mathrm{C}$ after the normal 2 to 7 days necessary for transit and handling. Neither transplant survival nor fruit yield was reduced after 5 days storage, but fruit yields were reduced by 10 days of storage.

Moran et al. (1962) reported that bare-root tomato plants shipped in perforated polyethylenelined crates arrived in the similar condition as the standard pack. As the number of perforations in the liners increased, less mold, heating, and leaf yellowing occurred in the plants. After 1962, bareroot transplants were loosely packed (1000/crate) intocrates in the field to reduce excessive physical damage caused by bundling.

The production of bare-root transplants in the south for use in northern production areas cannot always be timed for immediate delivery from the site of production to the area of use. Many times, weather conditions prevent immediate use of the transplant after arrival in the north. Also, conditions of storage during transit can greatly affect the transplant performance after arrival. In an experiment with four types of bare-root transplants, Risse et al. (1985) packed field-grown plants loosely (1000/crate), densely (1250/crate), with soil adhering to the roots (1000/crate), and moist plants with soil adhering to the roots (1000/ crate). The plants were then shipped from Georgia to Ohio. Densely packed plants had internal crate temperatures 4 to $5 \mathrm{C}$ higher than the other treatments. Plant survival and yields were reduced by dense packing. Another set of plants was packed loosely and stored for 4 days at $10,16,21$, or $27 \mathrm{C}$. As storage temperature increased, dry matter in the stems increased and transplant survival decreased.

Containerized transplants commonly are pulled by hand from growing trays and packed loosely ( $800+$ per box) in waxed, corrugated cartons for shipment in refrigerated trailers. Although recommended shipping temperatures are 10 to $16 \mathrm{C}$ for 3 to 4 days, it is common for plant temperatures to increase during shipment if the plants are not precooled properly prior to loading. In areas such as Florida, where producers are relatively close to the transplant growing source, transplants are shipped in the growing trays.

In an experiment with containerized transplants, Risse et al. (1979) conducted storage tests with Walter tomatoes grown and pulled from the cell trays and stored at temperatures from 5 to $21 \mathrm{C}$ for 5,10 , or 15 days. Plants stored at $5 \mathrm{C}$ maintained the highest plant vigor, although no wilt or decay was found at any temperature. In field tests, plants could be stored only 5 days at 5,13 , or $21 \mathrm{C}$; otherwise, plant survival, initial growth, and yield were affected adversely compared to a nonstored control.

In more recent work with containerized Sunny tomato transplants, Leskovar and Cantliffe $(1990,1991)$ examined transplant handling effects on early plant growth and yield after reducedambient-temperature storage conditions, Transplants either were pulled from the growing tray and packed at a density of 850 plants/carton or shipped directly in the transplant tray. Pulled transplants stored at $5 \mathrm{C}$ had longer stems, higher stem dry weights, more specific leaf area, highershoot: root ratios, and lower root dry weights than nonpulled transplants. Shoot growth of pulled transplants may have been promoted by higher air temperatures in the shoot and root environment caused by the build-up of respiration heat induced by high packing density (Risse et al., 1985). Root growth limitation in pulled transplants may have been caused by excess moisture and reduced oxygen availability in the root environment. Specific leaf area increased linearly from 0.213 to 0.250 $\mathrm{cm}^{2} \mathrm{mg}^{-1}$ as storage time increased from 0 to 8 days, indicating that growth was maintained pri- 
marily at the expense of roots. At $5 \mathrm{C}$, leaf area of pulled transplants increased for 4 days and increased leaf area by $35 \%$ more than that of nonpulled transplants. Nonpulled transplants maintained about the same initial leaf area for the duration of the experiment. Similar growth responses were found for plants stored at $15 \mathrm{C}$; however, leaf and stem growth continued to increase for 4 days and then decreased. Lower leaves began to turn yellow after 6 days, and leaf deterioration was accentuated after 8 days of storage.

High ethylene concentrations in the atmosphere can accelerate plant tissue senescence greatly (Abeles, 1973). Ethylene evolved at 2.5 $\mathrm{ml} \cdot \mathrm{g}^{-1}$ at $5 \mathrm{C}$ and $2.2 \mathrm{ml} \cdot \mathrm{g}^{-1}$ at $15 \mathrm{C}$ for nonpulled plants, and $5.3 \mathrm{ml} \cdot \mathrm{g}^{-1} \cdot \mathrm{h}^{-1}$ at $5 \mathrm{C}$ and 2.1 $\mathrm{ml} \cdot \mathrm{g}^{-1} \mathrm{~g} \cdot \mathrm{h}^{-1}$ at $15 \mathrm{C}$ for pulled plants (Leskovar and Cantliffe, 1991). Increased ethylene production in pulled plants at $5 \mathrm{C}$ might be attributed to the additive effects of excessive moisture, chilling temperature, and/or physical stress (Abeles, 1973). During $15 \mathrm{C}$ storage, basal roots formed from the hypocotyl, and proliferated in the upper rootmedia zone, which is a less-anaerobic environment than the lower root zone. This new root growth, more evident after 4 days, may have given access to oxygen, thus reducing ethylene accumulation in storage. In this study, transplants packed at 2350 plants $/ \mathrm{m}^{2}$ had significantly shorter stem length and lower leaf area, stem dry weight, and root dry weight than the nonpulled transplants packed at $658 \mathrm{plants} / \mathrm{m}^{2}$. Under high packing density, and in the presence of warmer air temperature in the dark, pulled plants might be expected to deteriorate faster than nonpulled plants. Pulled transplants had higher specific leaf area, lower root dry weight, and higher shoot: root ratio than nonpulled transplants after 2 days of storage.

Thus, plants left in the trays until field planting tend to have faster growth rates and larger fruit production than those pulled and packed. In the first and second fruit harvest, nonpulled transplants had more (3.7 and 3.2 tha ${ }^{-1}$, respectively) extra-large-size fruits than pulled transplants (2.2 and 1.9t:ha', respectively) (Leskovar and Cantliffe, 1991). Similarly, nonpulled plants produced $70 \%$ more total extra large fruits than pulled plants, but total marketable fruit yield was not affected by handling method. Increasing transplant storage time from 0 to 3 days generally did not decrease fruit yield, but yield of extra-large fruits decreased linearly from 3.5 to 2.4 tha ${ }^{-1}$ after transplant storage of 0 to 3 days.

These studies indicated that transplant maturity and handling affected transplant growth, especially after 4 days of storage at either 5 or $15 \mathrm{C}$. Forty-five-day-old nonpulled transplants maintained superior shoot and root characteristics compared to pulled transplants. Although temperatures between 10 and $13 \mathrm{C}$ are suggested to suppress root growth (Hardenburg et al., 1986), the above data clearly indicated that shoot and root growth continued at temperatures as low as $5 \mathrm{C}$.
After 6 days storage, plant separation was difficult due to root knitting in pulled transplants. Storage temperatures should be selected to avoid the possibility of chilling injury or physiological disorders that may be expressed after planting (Wien, 1990). Growth and fruit yield of 35-day-old transplants were more affected by transplant handling through pulling and packing than by leaving them in the original containers. Therefore, physical stresses of pulling and packing should be minimized. If planting is delayed beyond 2 days, storage at lower than ambient temperatures is desirable.

\section{Summary}

Transplants are grown and shipped locally or over long distances. Shipping conditions and time in transit depend on the distance traveled. Local growers may receive transplants in the trays in which they were grown, while those shipped long distances are pulled and then packed in cartons or crates. Field performance of transplants is directly related to seedling vigor at the time of transplanting. Factors that can affect transplant vigor negatively during growing and shipping include the plant-hardening techniques used, mechanical injury at any stage of plant growth, container cell size, age of the transplant, shipping and planting conditions, length and environmental conditions during transit, and storage length and conditions prior to transplanting. Mechanical injury begins as soon as the plants are removed from the tray, while reduced watering and/or fertilization during hardening may have a long-term effect on plant productivity. High temperatures during shipping, packing plants too densely, and prolonged storage in the dark can reduce subsequent yields. Knowledge of proper conditions for pre- and postharvest handling of transplants are not clearly understood by many transplant growers. This knowledge can improve greatly transplant vigor and potentially can give growers higher yields.

\section{Literature Cited}

Abeles, F.B. 1973. Ethylene in plant biology. Academic, London.

Carlson, W.H. 1990. Controlling transplant height. Amer. Veg. Grower, Apr. p. 16-18.

Dufault, R.J. 1986. Influence of nutritional conditioning on muskmelon transplant quality and early yield. J. Amer. Soc. Hort. Sci. 111:698-703.

Dufault, R.J. and R.R. Melton. 1990. Cyclic cold stresses beforetransplanting influence tomato seedling growth, but not fruit earliness, fresh-market yield, or quality. J. Amer. Soc. Hort. Sci. 115:559-563.
Hall, M.R. 1989. Cell size of seedling containers influences early vine growth and yield of transplanted watermelon. HortScience 24:771-773.

Hardenburg, R.E., A.E. Watada, and C.Y. Wang. 1986. The commercial storage of fruits, vegetables, and florist and nursery stocks. USDA Agr. Hdbk. 66.

Harmon, R., L.A. Weston, and T. Jones. 1991. Effect of root cell size and transplant age on yield of transplanted eggplant. HortScience 26:689.(Abstr.)

Hickman, G.W. E.J. Perry, R.J. Mullen, and R. Smith. 1989. Growth regulator controls tomato transplant height. Calif. Agr. Sept./Oct. p. 19-20.

Jaworski, C.A. 1966. Clipping vs. non-clipping for size uniformity of tomato transplants. Proc. Fla. State Hort. Soc. 79:209-211.

Jaworski, C.A. and R.E. Webb, 1966. Influence of nutrition, clipping and storage of tomato transplants on survival and yield. Proc. Fla. State Hort. Soc. 79:216-221.

Jaworski, C.A., R.E. Webb, G.E. Wilcox, and S.A. Garrison. 1969. Performance of tomato cultivars after various types of transplant clipping. J. Amer. Soc. Hort. Sci. 94:614-616.

Jaworski, C.A., R.E. Webb, and S.A. Garrison. 1970. Growth-retardant-treated tomato transplants. HortScience 5:255-256.

Jones, R.T., L.A. Weston, and R. Harmon. 1991. Effect of root cell size and transplant age on cole crop yields. HortScience 26:688. (Abstr.)

Kratky, B.A., J.K Wang, and K. Kubojiri. 1982. Effects of container size, transplant age, and plant spacing on Chinese cabbage. J. Amer. Soc. Hort. Sci. 107:345-347.

Latimer, J.G. 1991. Mechanical conditioning for control of growth and quality of vegetable transplants. HortScience 26:1456-1461.

Latimer, J.G. and P.A. Thomas. 1991. Application of brushing for growth control of tomato transplants in a commercial setting. HortTechnology 1(1):109-110.

Leskovar, D.I. and D.J. Cantliffe. 1990. Does the initial condition of the transplants affect tomato growth and development? Proc. Fla. State Hort. Soc. 103:148-153.

Leskovar, D.I. and D.J. Cantliffe. 1991. Tomato transplant morphology affected by handling and storage. HortScience 26:1377-1379. 
Leskovar, D.I., D.J. Cantliffe, and P.J. Stoffella. 1990. Root growth and root-shoot interaction in transplants and direct-seeded pepper plants. Environ, Expt. Bot. 30:349-354.

Leskovar, D.I., D.J. Cantliffe, and P.J. Stoffella. 1991. Growth and yield of tomato plants in response to age of transplants. J. Amer. Soc. Hort. Sci. $116: 416-420$.

Marr, C.W. and M. Jirak. 1990. Holding tomato transplants in plug trays. HortScience 25:173176.

McCarter, S.M. and C.A. Jaworski. 1968. Greenhouse studies on the spread of Pseudomonas solanacearum in tomato plants by clipping. Plant Dis. $52: 330-334$.

Moran, C.H., R.E. Hardenburg, R.D. Peel, and J.F. Moore. 1962. Commercial packaging and truck transportation of bare root tomato plants in polyethylene-lined crates. Proc. Amer. Soc. Hort. Sci. 81:458-466.

Nicklow, C.W. and P.A. Minges. 1962. Plant growing factors influencing the field performance of the fireball tomato variety. J. Amer. Soc. Hort Sci. 81: 443-450.

Orzolek, M.D. 1989. Growth retardants improve plant performance. Amer. Veg. Grower. May. p. 42-44.

Pisarczyk, J.M. and W.E. Splittstoesser. 1979. Controlling tomatotransplant height with chlormequat, daminozide, and ethephon. J. Amer. Soc. Hort. Sci. 104:342-344.

Price, H.C. and B.H. Zandstra. 1988. Maximize transplant performance. Amer. Veg. Grower. Apr. p. 10-16.

Risse, L.A., D.W. Kretchman, and C.A. Jaworski. 1985. Quality and field performance of densely packed tomato transplants during shipment and storage. HortScience 20:438-439.
Risse, L.A., T. Moffitt and H.H. Bryan. 1979. Effect of storage temperature and duration on quality, survival, and yield of containerized tomato transplants Proc. Fla. State Hort. Soc. 92:198-200.

Taha, A.A., D.W. Kretchman, and C.A. Jaworski. 1980. Effect of daminozide and ethephon on transplant quality, plant growth and development, and yield of processing tomatoes. J. Amer. Soc. Hort. Sci. 105:705-709.

Wang, J.K. and B. Kratky. 1976. Seedling transplant and its effects on mechanized greenhouse lettuce production. Trans. Amer. Soc. Agr. Eng. p. 661-663.

Weston, L.A. 1988. Effect of flat cell size, transplant age, and production site on growth and yield of pepper transplants. HortScience 23:709-711.

Weston, L.A. and B.H. Zandstra. 1983. Bigger transplants mean larger early yields. Amer. Veg. Grower. Dec. p. 24-28.

Weston, L.A. and B.H. Zandstra. 1986. Effect of root container size and location of production on growth and yield of tomato transplants. J. Amer. Soc. Hort. Sci. 111:498-501.

Weston, L.A. and B.H. Zandstra. 1989. Transplant age and $N$ and $P$ nutrition effects on growth and yield of tomatoes. HortScience 24:88-90.

Wien, H.C. 1990. Dont cool tomato transplants. Amer. Veg. Grower. Feb. p. 34-36.

Wood, R.J. 1988. Progress with cell transplants. New Zealand Comm. Grower, June. p. 23-24.

Wurr, D.C.E. and J.R. Fellows. 1986. The influence of transplant age and raising conditions on the growth of crisp lettuce plants raised in Techniculture plugs. J. Hort. Sci. 61:81-87.

Wurr, D.C.E., E.F. Cox, and J.R. Fellows. 1986. The influence of transplant age and nutrient feeding regime on cauliflower growth and maturity. J. Hort. Sci. 61:503-508. 